\title{
RISK ANALYSIS IN MAINTENANCE PROCESSES
} pages: $64-76$

\section{PRZEMYSŁAW DROŻYNER}

\begin{abstract}
A B S T R A C T
The article aims to present practical methods for prioritising the activities of maintenance departments based on the Pareto analysis and the failure risk analysis. Based on the collected data on the number of observed failures and their removal times, commonly known reliability indicators were determined, which were then used to estimate the probabilities and consequences of failures in terms of the risk of loss of production continuity. Based on commonly collected failure data, the developed methods allow proposing to the maintenance departments the sequence of maintenance and repair work to be undertaken in terms of minimising the risk of failure. Risk analysis is somewhat commonly used in the practice of maintenance departments (e.g. RBI, FMEA, ETA, FTE, HIRA). The added value of this work is the use of reliability indicators for estimating the values of risk components, i.e., probability and consequences. The method was developed on the basis of operational data collected in one of the plants of the dairy cooperative and, after assessing the effects of its implementation, it was implemented in other enterprises of the cooperative.
\end{abstract}

KEY WORDS

risk analysis, maintenance, reliability

10.2478/emj-2020-0028
Corresponding author:

Przemysław Drożyner

University of Warmia and Mazury in Olsztyn, Poland ORCID 0000-0002-6125-8035 e-mail: przemas@uwm.edu.pl

\section{INTRODUCTION}

In ancient times, the failure-free use of technical inventions was the intention of their creators who also understood that this effect was impossible without periodic, more or less complex maintenance activities. Archaeological findings in prehistoric burial places include, e.g., chariots with traces of grease on their axles, and - speaking in modern terms catalogues of vegetable oils and animal fats to be used as lubricants.

Drożyner, P. (2020). Risk analysis in maintenance processes. Engineering Management in Production and Services, 12(4), 64-76. doi: 10.2478/emj-2020-0028 
Throughout history, the concepts of servicing technical facilities have changed. Until the Second World War, such services were mainly understood (apart from cleaning and the aforementioned lubrication) as a reaction to damage. In times of cheap and readily available labour, the reactive approach was predominant. It meant that machines and devices were serviced only when their technical condition required it. Therefore, maintenance activities were most often performed as a reaction to a failure.

In the following decades, machines grew much more complex, making a greater impact on the continuity of production. In the event of a failure, it was no longer possible to replace the operation of these machines with human force, and downtime caused increasingly more economic losses. Along with the increase in the complexity of machine construction, preventive and prognostic concepts emerged, but they still referred to the effectiveness of maintenance activities, i.e., eliminating failures and maintaining the production continuity. Since the end of the last century, the increasing importance of operational efficiency, safety of people and the environment, compliance with the law and standards, and more recently, sustainable development have been recognised.

Maintenance tasks are interdisciplinary. Not only they consist of technical issues (degradation, wear, diagnostics, technical and technological progress) but also legal, normative and managerial issues, which must be resolved to achieve production, quality, environmental and work safety goals. The list of maintenance attributes is no longer limited to the ability to efficiently use workshop tools and quickly locate damage. The contemporary aspects of maintenance include the origin and forecasting of a technical condition, product quality, the safety of people and the environment, and technical and technological development. Such an approach to maintenance processes creates the need to develop or adopt appropriate tools and methods that will allow making effective and efficient decisions regarding the determination of the sequence and scope of maintenance, repair or investment activities.

\section{LITERATURE REVIEW}

The concept of maintenance appears in terms of inevitable costs which, according to various sources, amount to as much as $5 \%$ of the company's turnover, constituting $4-15 \%$ of the production costs and about
$18 \%$ of the inventory value depending on the industry (Mikler, 2008). Some sources estimate that the cost of living amounts to 10-40\% (Maggard \& Rhyne, 1992), 15-50\% (Coetzee, 2004), and even 15-70\% (Bevilacqua \& Braglia, 2000) of production costs. According to Ahlmann (2002), the costs of maintaining machinery in Sweden accounts for $6.2 \%$ of the company's turnover. According to Wireman (1990), 30\% of the costs incurred for maintenance arise from improper planning of works and related overtime. The actual costs incurred can be much higher.

Machine failure may entail financial losses not only because of the necessity to remove it but also due to the lack of planned production or penalties related to failure to meet deadlines or environmental pollution (Todinov, 2006). Increasingly more often, insurance companies require maintenance, which is safe in the economic, environmental and health-and-safety terms, basing insurance rates on the effectiveness of this process. Enterprises with high organisational and technical culture are therefore changing their attitude to maintenance processes and ceasing to classify them as costs that need to be minimised, perceiving them as costs that can and must be managed instead. Concepts of proactive maintenance, such as TPM, RCM, RBI, consist of monitoring the technical condition of machines, introducing technical diagnostics, and device operators. These concepts, as well as various approaches to the principles of maintenance, have been widely described in the literature (Żółtowski \& Niziński, 2010; Legutko, 2010; Niziński \& Michalski, 2007; Legutko, 2007; Pintelon et al., 2006; Żółtowski \& Tylicki, 2004; Żurek, 2004; Szpytko et al., 2003; Swanson, 2001).

Enterprises with advanced organisational culture and technologies recognise that not only maintenance processes may have a significant impact on the production output, costs and quality of the final product but also the safety of people and the environment. Maintenance is perceived as an important element of sustainable development (Szczuka \& Drożyner, 2015; Jasiulewicz-Kaczmarek \& Drożyner, 2013; Drożyner et al., 2011; Farrington-Darby et al., 2005; Fei \& Honghui, 1998). Maintenance services are becoming an indispensable element of most business processes, such as production planning to ensure continuity, logistics and sales, environmental protection or HR processes (competences, authorisations, staff working hours), including occupational health and safety.

Besides, maintenance services are responsible for (right and wrong) decisions regarding required maintenance and repair activities, such as machine inspec- 
tion, alignment or balancing. Their choice of an operation strategy or purchasing policy may either positively or negatively influence technical and technological development and, as a consequence, the efficiency and effectiveness of the entire enterprise. Therefore, maintenance is a part of such standards as ISO 55001:2014 on asset management. The guidelines for the implementation of an asset management system contained in the ISO 55002 standard suggest the use of such methods and tools as RCM, FMEA, HAZOP, and RCFA (Root Cause Failure Analysis). The comparison of the requirements of ISO 9001 and ISO 55001 in terms of maintenance processes and, more broadly, operation reveals that infrastructure (physical assets) is treated objectively in the ISO 9001 standard (as an intermediary). In contrast, ISO 55001 treats the assets as the main subject and the purpose of action.

The quality standard refers to the infrastructure instrumentally as one of many factors influencing the quality of the product or service. The requirements for infrastructure generally relate to the effectiveness of maintenance, which aims to ensure timely service considering the risk of a potential failure and downtime, and, sometimes, also the quality requirements for the product, which is potentially at risk due to inadequate technical condition of the facility. The process approach to these issues - although ensuring greater operational efficiency - is not required directly and is the sole decision of the entrepreneur.

The ISO 55001 standard specifies all elements of the process approach to infrastructure management, i.e., requirements for the setting (organisation context), planning, identifying measures, and ensuring resources. Also, it concerns typical systemic actions, such as internal audits, management reviews, corrective, preventive and improvement measures. The standard considers assets as a value that can and must be managed rather than inevitable costs. This standard is in line with the proposed (Jasiulewicz-Kaczmarek \& Drożyner, 2011; Jasiulewicz-Kaczmarek \& Drożyner, 2013; Drożyner et al., 2013) and the model of machine maintenance processes.

Companies that have implemented formalised management systems for quality, environmental protection, health and safety, etc., are obliged to meet the requirements of relevant standards for continuous improvement. Various tools and methods are used in such activities, e.g., brainstorming, histograms, 5 Whys, the Pareto analysis, the Ishikawa diagrams, and the G8D method (Starzyńska et al., 2010; Mazur \& Gołaś, 2010). These tools are generally used to improve management and production processes, and, rarely, auxiliary processes, such as maintenance. Meanwhile, a good product is not enough for a business to maintain a position in the market. Nowadays, competition demands greater efforts, and enterprises that do not minimise losses in production have difficulty with staying in the market (Jasiulewicz-Kaczmarek, 2013; Stanek et al., 2011; Saniuk et al., 2015). Therefore, cost optimisation should apply to all processes, especially those that may generate high costs (Stuchly, Jasiulewicz-Kaczmarek, 2014; Pałucha, 2015; Knights, 2001; Obora, 2008).

The widespread use of classical analysis tools for maintenance processes began with the advent of the TPM (Total Productive Maintenance) concept. The tools are used in maintenance to analyse the causes of damage (5 Whys, the Ishikawa diagram (Chang \& Lin, 2006)), the prioritisation of maintenance activities (the Pareto analysis (Borris, 2006)), the process improvement (brainstorming (Drożyner \& Hoffa, 2015)). The tools have been practically used in the railway (Kumar et al., 2008), aviation (Al-kaabi et al., 2007; Vassilakis \& Besseris, 2009), automotive (Holtz \& Campbell, 2003), metallurgy (Gajdzik, 2014) and petrochemical (Prasanna \& Desai, 2011) industries.

The maintenance of machinery and equipment depends on the context of the enterprise, its goals, structure, internal limitations and external conditions. Components of the maintenance are the result of (1) units targeted by activities, i.e., specific machines and their modules that require inspection, maintenance, and repair; (2) the company's status in relation to the environment, in which it operates; (3) goals that reflect the strategic importance of the company's maintenance; (4) profile of maintenance tasks; and (5) the results achieved in relation to the expected value. The effectiveness of maintenance management in the enterprise is significantly impacted by such factors as the risk assessment of emergency events, the selection of an operational strategy, and the determination of time intervals and resources necessary to implement the tasks resulting from the adopted strategy (Jasiulewicz-Kaczmarek \& Bartkowiak, 2016). The new trend of maintenance management has shifted from time interval-based maintenance to risk approach-based maintenance. Risk assessment integrates reliability with safety and environmental issues and can, therefore, be used as a decision-making tool in preventive maintenance planning (Ratnayake \& Antosz, 2017; Gill, 2017; Gallaba et al., 2019; Hameed et al., 2019; Özcan et al., 
Tab. 1. Risk analysis tools used for maintenance

\begin{tabular}{|c|c|c|}
\hline RISK TOOL & DESCRIPTION & SAMPLE PUBLICATIONS ON THE ISSUE \\
\hline ETA & $\begin{array}{l}\text { Event Tree Analysis - a method for describing the consequences of the } \\
\text { superior event, illustrating the progression of events from the initial } \\
\text { event to the final event, with particular emphasis on the moments that } \\
\text { are decisive for the condition of the facility (installation). It is the } \\
\text { primary method of creating an object model for threat analysis }\end{array}$ & $\begin{array}{l}\text { Ahmadi et al., 2008; } \\
\text { Mareş et al., } 2017\end{array}$ \\
\hline FTA & $\begin{array}{l}\text { Fault Tree Analysis - a qualitative method of risk analysis using the } \\
\text { structure of logical trees, allowing for modelling the course of a failure } \\
\text { and then its analysis. An FTA diagram illustrates causes, the result of } \\
\text { which are referred to as uncertain events or risk }\end{array}$ & $\begin{array}{l}\text { Gharahasanlou et al., 2014; } \\
\text { Vaurio, } 2010\end{array}$ \\
\hline FMEA & $\begin{array}{l}\text { Failure Modes Effects Analysis - a method that consists of analytically } \\
\text { determining the cause-and-effect relationships of potential product } \\
\text { defects and considering the criticality (risk) factor in the analysis. Its aim } \\
\text { is to consistently and systematically identify potential product/process } \\
\text { defects, and then eliminate them or minimise the related risk }\end{array}$ & $\begin{array}{l}\text { Sutrisno et al., 2015; } \\
\text { Onodera \& Katsushige, 1997; } \\
\text { Braaksma et al., 2013; } \\
\text { Mikołajczyk, 2013; } \\
\text { Mańka, 2015; } \\
\text { Ennouri, } 2015\end{array}$ \\
\hline HAZOP & $\begin{array}{l}\text { Hazard and Operability Studies, in other words, the analysis of threats } \\
\text { and operational capabilities, is based on the PN-IEC } 61882 \text { standard. It } \\
\text { is often used in the design of new facilities and installations, } \\
\text { modernisation of facilities, installations or processes }\end{array}$ & $\begin{array}{l}\text { Hu et al., 2012; } \\
\text { Crawley \&Tyler, } 2015\end{array}$ \\
\hline HIRA & $\begin{array}{l}\text { Hazard Identification and Risk Assessment - risk assessment tool that } \\
\text { can be used to assess which hazards pose the greatest risk in terms of } \\
\text { how likely they are to occur and how great their potential impact may } \\
\text { be }\end{array}$ & $\begin{array}{l}\text { Purohit et al., 2018; } \\
\text { Liberti et al., } 2015\end{array}$ \\
\hline GOFA & $\begin{array}{l}\text { Goal-Oriented Failure - analysis and a hazard identification technique } \\
\text { that uses selective features from Failure Mode and Effects Analysis } \\
\text { (FMEA) and Fault Tree Analysis (FTA) to identify the causes of failure of } \\
\text { a specific target }\end{array}$ & $\begin{array}{l}\text { Yi et al., 2017; } \\
\text { Yi et al., } 2016\end{array}$ \\
\hline $\mathrm{RBI}$ & $\begin{array}{l}\text { Risk-Based Inspection - determining the scope and methods of testing, } \\
\text { allowing to determine the risk associated with the operation of } \\
\text { technical devices, based on the results of quantitative risk analysis }\end{array}$ & $\begin{array}{l}\text { Arunraj \& Maiti, 2007; } \\
\text { Khan et al., 2004; } \\
\text { Khan \& Haddara,2003 }\end{array}$ \\
\hline RCM & $\begin{array}{l}\text { Reliability-Centred Maintenance - determining the necessary } \\
\text { maintenance activities in the operational efficiency of the machine or } \\
\text { device, considering the conditions of use }\end{array}$ & $\begin{array}{l}\text { Hauge et al., 2001; } \\
\text { Braglia et al., } 2019\end{array}$ \\
\hline
\end{tabular}

2019; Michalak, 2017). Risk-based maintenance planning minimises the probability of a system failure and its consequences related to safety, economy and the environment (Jasiulewicz-Kaczmarek et al., 2020). It assists management in making the right maintenance investment decisions, which, in turn, results in better use of existing production equipment. In recent years, there has been a growing interest in the use of risk analysis and risk-based (informed) approaches for guiding decisions on maintenance (Table 1).

\section{RESEARCH METHODS}

One company from the food processing industry (dairy) was used to compile data on the frequency and duration of emergency downtime. During the analysed period (20 months), 132 defects were recorded, the removal of which took a total of 241 hours (Table 2).

First, a Pareto analysis was performed for the damage that occurred, considering first the time of their removal and then, their number as a criterion. When conducting the analysis, two variants of the procedure were considered. In the first one (V1), each operated device was studied separately. In the second (V2), whole homogeneous groups of devices (such as tanks) were studied separately (as a single unit). As the Pareto analysis is widely described in the literature (Karuppusami, Gandhinathan 2006; Talib et al., 2010; Miller 2011), the description is not provided in this paper. The results of the analysis are presented in Figs. 1-4. 
Tab. 2. List of the frequency and duration of emergency downtime at the enterprise

\begin{tabular}{|c|c|c|c|c|c|c|}
\hline EQUIPMENT & $\begin{array}{c}\text { UNITS OF EQUIP- } \\
\text { MENT }\end{array}$ & $\begin{array}{c}\text { CODE OF EQUIP- } \\
\text { MENT }\end{array}$ & $\begin{array}{l}\text { NUMBER OF } \\
\text { FAILURES N, IN } \\
\text { THE ANALYSED } \\
\text { PERIOD }\end{array}$ & $\begin{array}{l}\text { NUMBER OF } \\
\text { FAILURES PER } \\
\text { EQUIPMENT }\end{array}$ & $\begin{array}{l}\text { TOTAL TIME T, OF } \\
\text { DAMAGE RE- } \\
\text { MOVAL [H] }\end{array}$ & $\begin{array}{l}\text { TIME T, OF DAM- } \\
\text { AGE REMOVAL } \\
\text { FOR SINGLE } \\
\text { EQUIPMENT }[\mathrm{H}]\end{array}$ \\
\hline horizontal tank & 7 & hori & 35 & 5 & 70 & 2 \\
\hline $\begin{array}{l}\text { submersible } \\
\text { pump }\end{array}$ & 20 & subm & 40 & 2 & 40 & 1 \\
\hline washing station & 2 & wash & 8 & 4 & 24 & 3 \\
\hline condensing unit & 1 & cond & 5 & 5 & 15 & 3 \\
\hline water boiler & 1 & wate-b & 5 & 5 & 10 & 2 \\
\hline $\begin{array}{l}\text { shrink wrapping } \\
\text { machine }\end{array}$ & 1 & shri & 3 & 3 & 9 & 3 \\
\hline $\begin{array}{l}\text { pneumatic } \\
\text { pump for cheese }\end{array}$ & 1 & pneu & 3 & 3 & 9 & 3 \\
\hline $\begin{array}{l}\text { centrifuge LWG- } \\
47\end{array}$ & 1 & cent & 3 & 3 & 9 & 3 \\
\hline $\begin{array}{l}\text { pneumatic press } \\
\text { of cheeses }\end{array}$ & 1 & pneu1 & 4 & 4 & 8 & 2 \\
\hline $\begin{array}{l}\text { milk collection } \\
\text { station }\end{array}$ & 1 & milk & 4 & 4 & 8 & 2 \\
\hline cheese cauldron & 1 & chee-c & 3 & 3 & 6 & 2 \\
\hline $\begin{array}{l}\text { vacuum packing } \\
\text { machine }\end{array}$ & 1 & vacu & 3 & 3 & 6 & 2 \\
\hline $\begin{array}{l}\text { cheese slurry } \\
\text { pump }\end{array}$ & 1 & chee-s & 3 & 3 & 6 & 2 \\
\hline hot water pump & 3 & hot & 3 & 1 & 6 & 2 \\
\hline water cooler & 1 & wate-c & 2 & 2 & 6 & 3 \\
\hline $\begin{array}{l}\text { pasteuriser - } \\
\text { milk - cream }\end{array}$ & 1 & past & 4 & 4 & 4 & 1 \\
\hline $\begin{array}{l}\text { centrifugal } \\
\text { pump }\end{array}$ & 1 & centp & 2 & 2 & 2 & 1 \\
\hline $\begin{array}{l}\text { screw compres- } \\
\text { sor }\end{array}$ & 1 & scre & 1 & 1 & 2 & 2 \\
\hline elevator & 1 & elev & 1 & 1 & 1 & 1 \\
\hline together & & & 132 & 58 & 241 & 40 \\
\hline
\end{tabular}




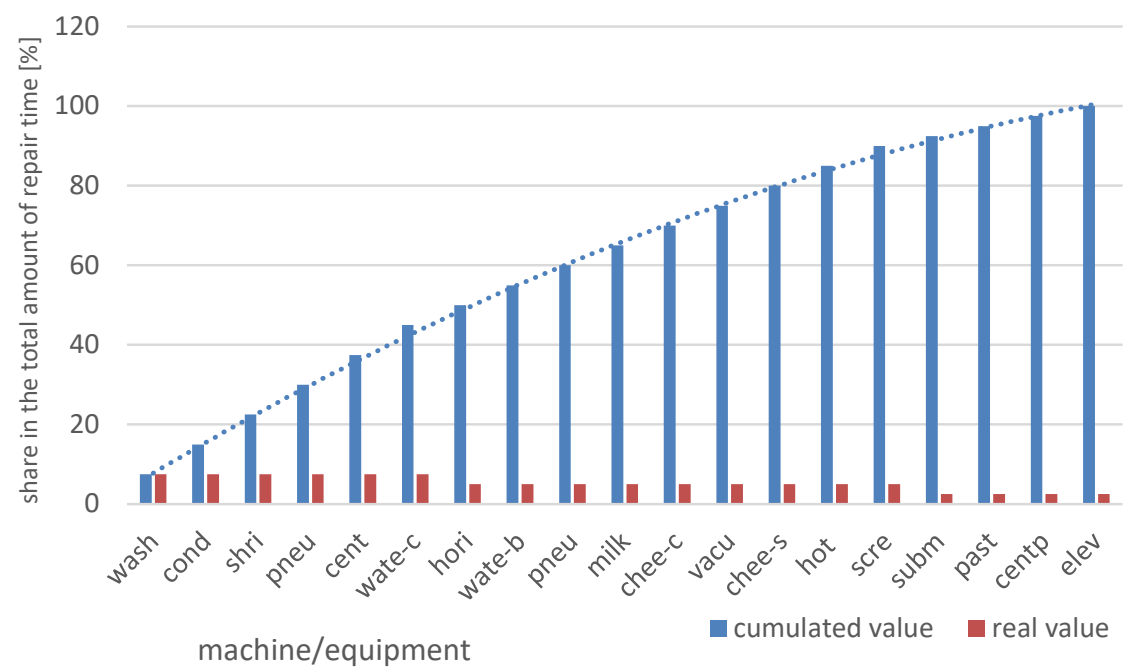

Fig. 1. Result of the Pareto analysis for the "repair time" criterion in the V1 variant

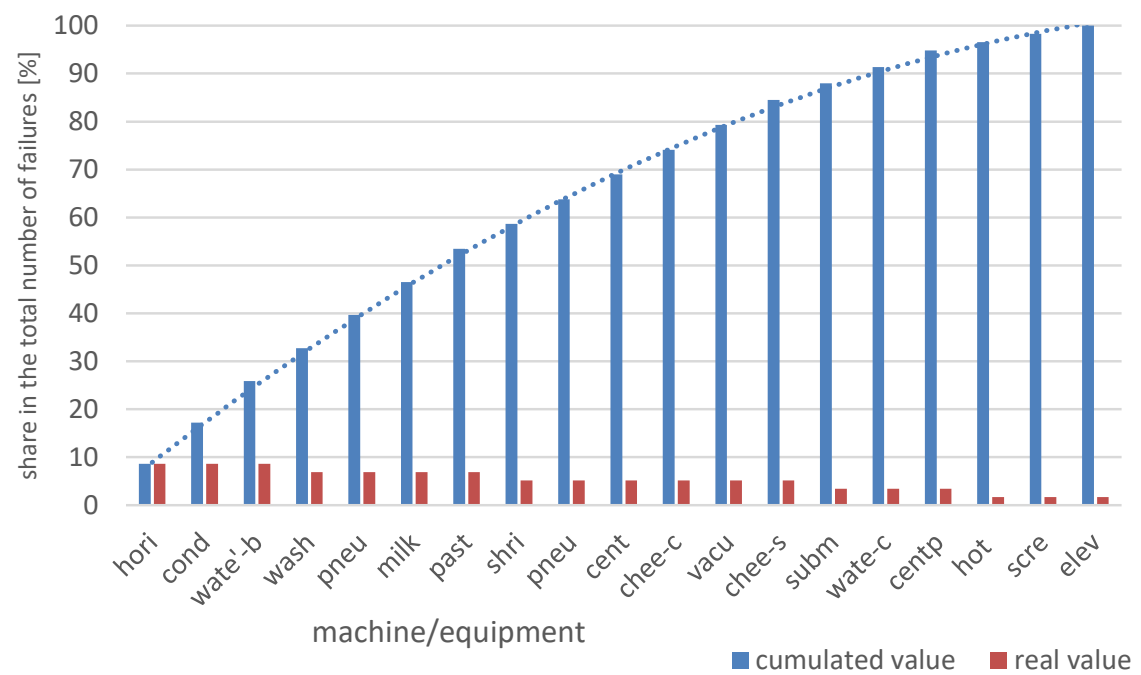

Fig. 2. result of the Pareto analysis for the "number of failures" criterion in variant V1

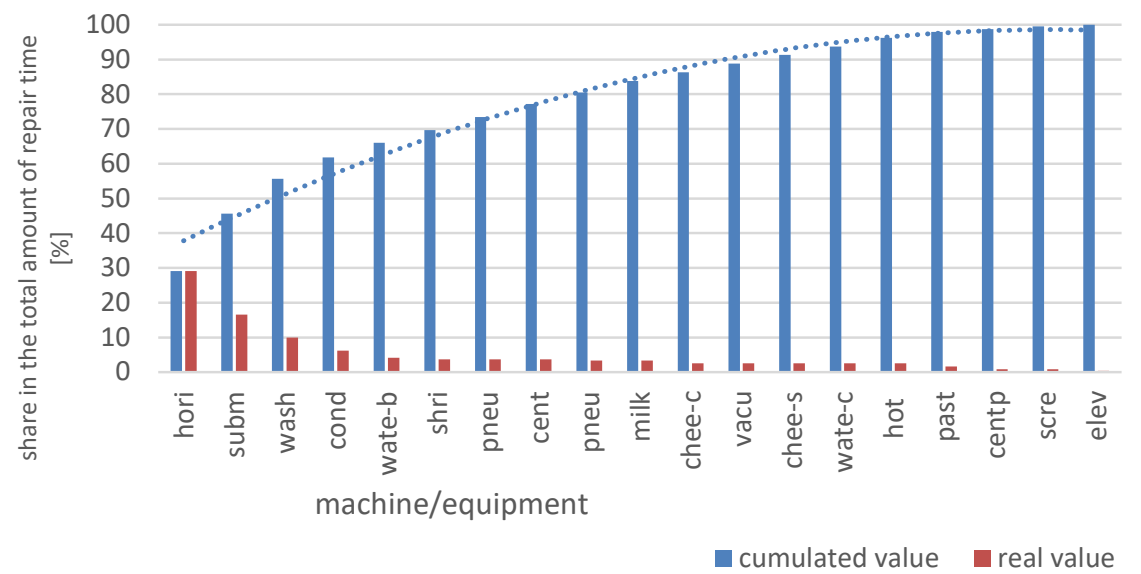

Fig. 3. Result of the Pareto analysis for the "repair time" criterion in the V2 variant 


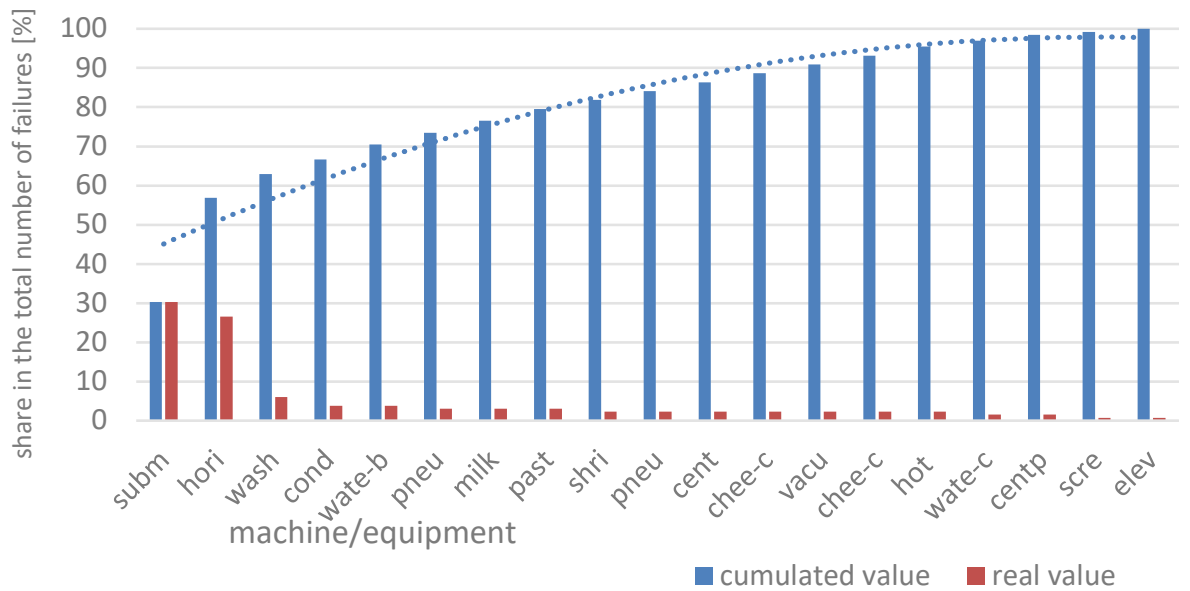

Fig. 4. Result of the Pareto analysis for the "number of failures" criterion in the V2 variant

It was found that in variant $\mathrm{V} 1$, when using the repair time criterion, the most important damages with the total share in the criterion of $80 \%$ were those that happened at the washing station, the condensing unit and the shrink-wrapping machine. In the case of the failure number criterion, the most important damages were those that were found at the horizontal tank, condensing unit and water boiler. In variant V2, when using the repair time criterion, the most important damages were those that took place were at the horizontal tank, submersible pump and washing station. And using the criterion of the number of failures, the most important damages were those that occurred at the submersible pump, the horizontal tank and the washing station. In the next step, it was decided to carry out the analysis using the method proposed by Knights (2001). This method allows for the simultaneous study of the influence of two criteria as opposed to the traditional Pareto method, where the influence of only one factor can be determined and visualised at one time, as shown in Figs. 1-4.

Figs. 5 and 6 show the location of individual pieces of equipment (their codes) in the coordinate system "number of failures" and "repair time" for both variants of analyses. This type of analysis allows for a certain grouping of equipment from the point of view of the product depending on the frequency and duration of failures. It is possible to easily visualise pieces of equipment, for which failures are chronic (relatively frequent) and those that, even in the case of a single incident, are significant for the company (due to the time required for removal). It was assumed that the threshold value of the number of failures $\mathrm{L}$ for chronic failures is:

$$
L=\frac{N}{p}
$$

where:

$\mathrm{N}-$ total number of damage incidents,

$\mathrm{p}-$ number of pieces of equipment (19 in variant V1 and 47 in V2),

and for severe damage, the average repair time $\mathrm{K}$ is:

$$
K=\frac{T}{N}
$$

where:

$\mathrm{T}$ - total damage removal time.

For the collected data, $\mathrm{L}=6.9$ failures per piece of equipment and $\mathrm{K}=1.8 \mathrm{~h}$ per failure in variant $\mathrm{V} 1$ and $\mathrm{L}=2.8$ failures per piece of equipment and $\mathrm{K}=1.8 \mathrm{~h}$ per failure in variant V2 were calculated. These limits are presented in Figs. 5 and 6. Pieces of equipment were classified depending on types of failure, i.e., chronic, major, chronic and serious, and less significant. A logarithmic scale was used to make the chart more readable. "L" - vertical line, "K" - horizontal line.

Based on this approach, the most important pieces of equipment were the shrink-wrapping machine, the centrifuge LWG-47, the pneumatic press for cheeses, the washing station, the condensing unit, the cheese slurry pump, the cheese cauldron, th $\epsilon$ vacuum packing machine, the pneumatic pump for cheese, the milk collection station, the water boiler and the horizontal tank in variant $\mathrm{V} 1$ and the horizontal tank, the submersible pump and the washing station in variant V2. As the use of risk analysis methods is becoming increasingly more 


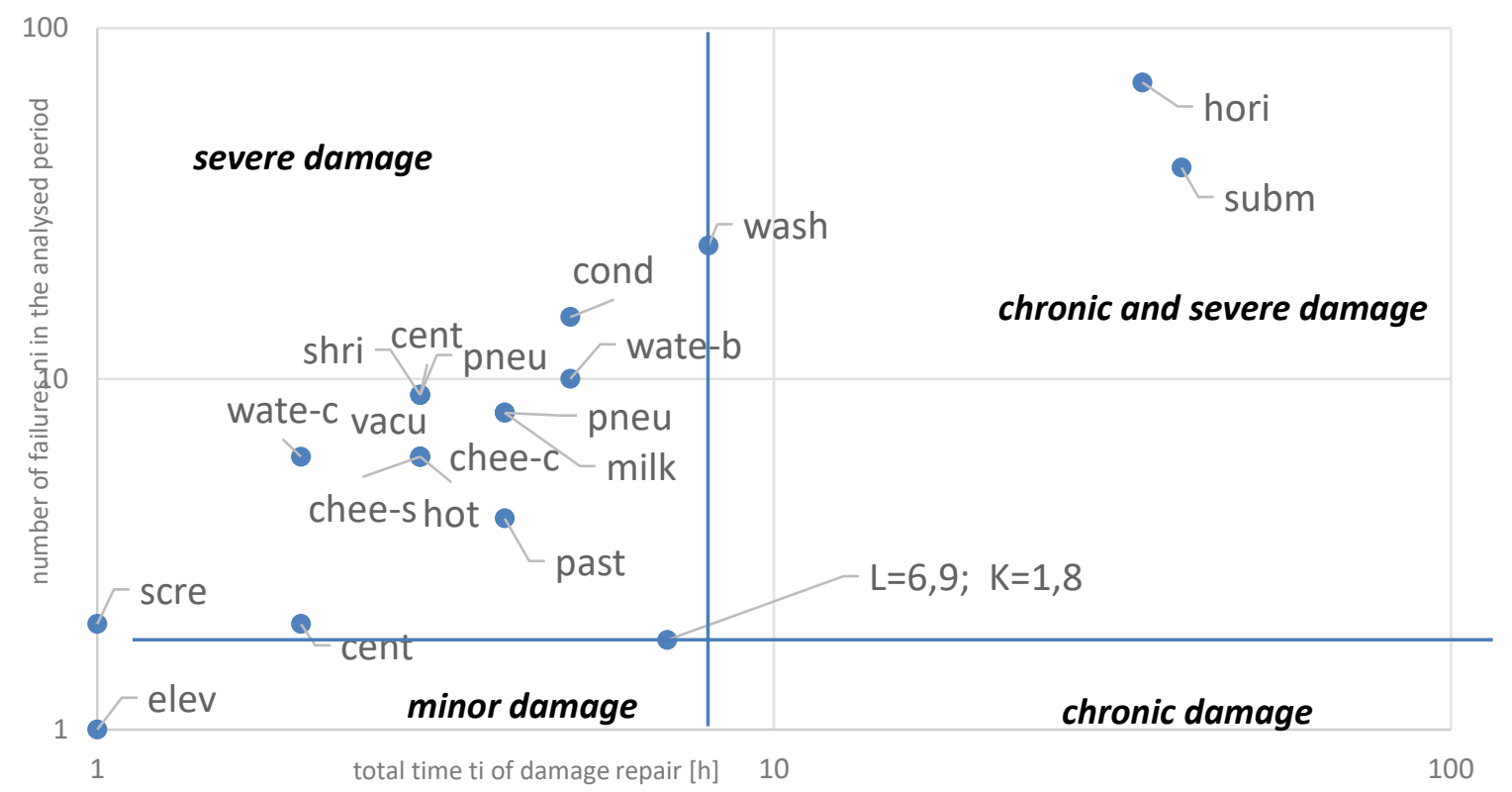

Fig. 5. Tested equipment and the "number of failures - failure recovery time" (V2) system

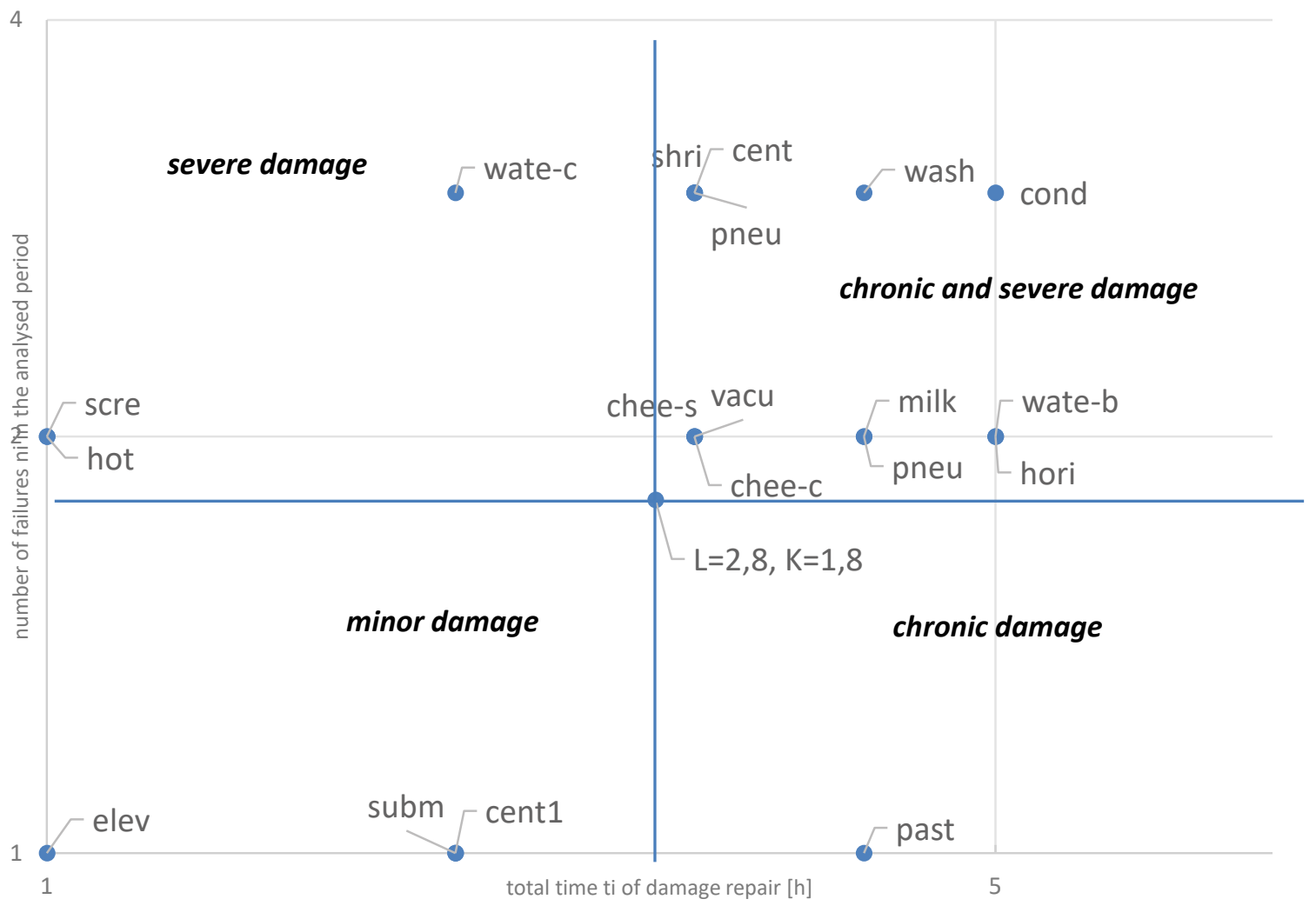

Fig. 6. Tested equipment and the "number of failures - failure recovery time" (V1) system 
common for the issues related to machinery and equipment operation, including maintenance (Weber et al., 2012; Aven, 2008; Khan et al., 2004), an original risk assessment method was proposed for further analyses related to failures of individual pieces of equipment with the use of reliability indicators to estimate the probability and consequences of failures. For this purpose, the average times of correct operation between failures for individual pieces (MTBFi) and the share of time ki in repairing the $i$-th device in the total working time of the company in the examined period $\mathrm{T}_{\mathrm{c}}$ (based on accounting data, 4000 hours of operation in the analysed period were assumed) and the damage stream $\lambda_{1}$ for the $i$-th device, where:

$$
\operatorname{MTBF}_{i}=\frac{T_{c}}{n_{i}}
$$

$$
\begin{gathered}
\lambda_{i}=\frac{1}{M T B_{i}} \\
k_{i}=\frac{t_{i}}{T_{c}}
\end{gathered}
$$

It was assumed that the measure of the probability of a failure will be the value of the failure stream $\lambda 1$, and a measure of consequence - the share of repair time for a given piece of equipment in the total operating time of $\mathrm{k}_{\mathrm{i}}$. The acceptable risk area (the green area in Figs. 7 and 8 ) was the area limited by the values of $\lambda_{1} i k_{i}$ equal to $1 / 3$ of the maximum values of $\lambda_{1} \mathrm{i} \mathrm{k}_{\mathrm{i}}$, respectively $\lambda_{\text {accept }}=0.0033$ and $\mathrm{k}_{\text {accept }}=0.0058$ (in the variant V1) and $\lambda_{\text {accept }}=0.000433$ and $\mathrm{k}_{\text {accept }}=1.04 \mathrm{E}-07$ (V2). In turn, the increased risk (the yellow area) is determined (arbitrarily) by values that are twice as high.

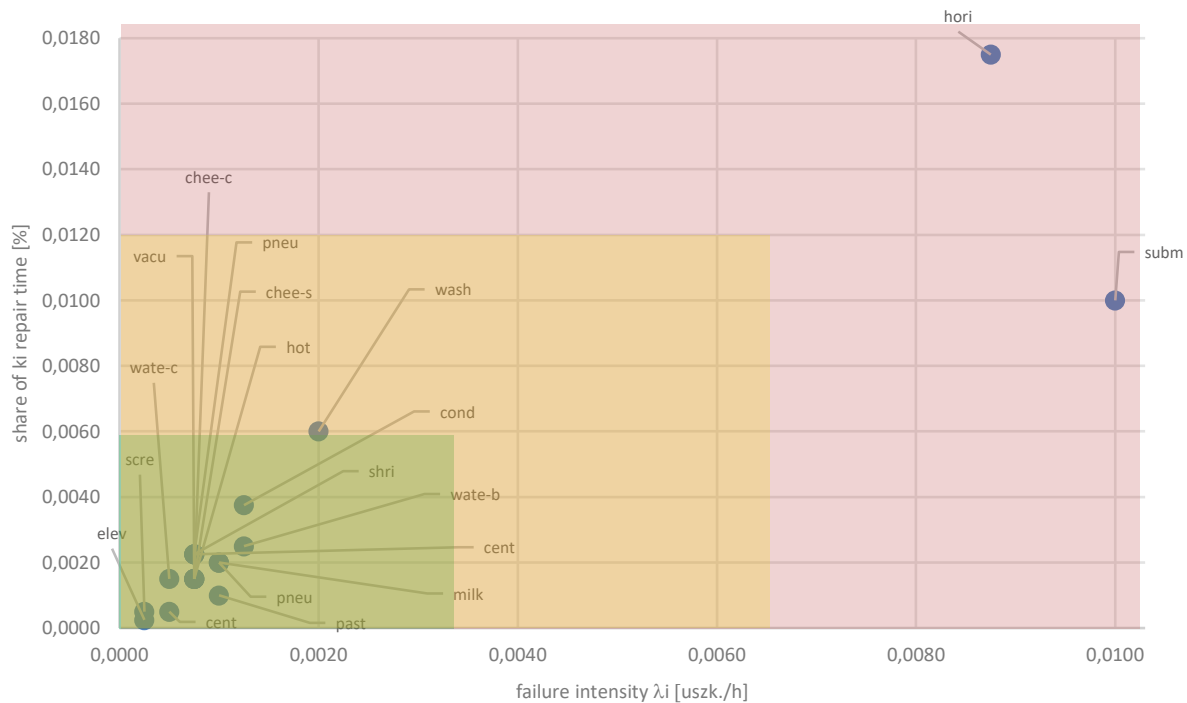

Fig. 7. Risk matrix for the tested devices (V2)

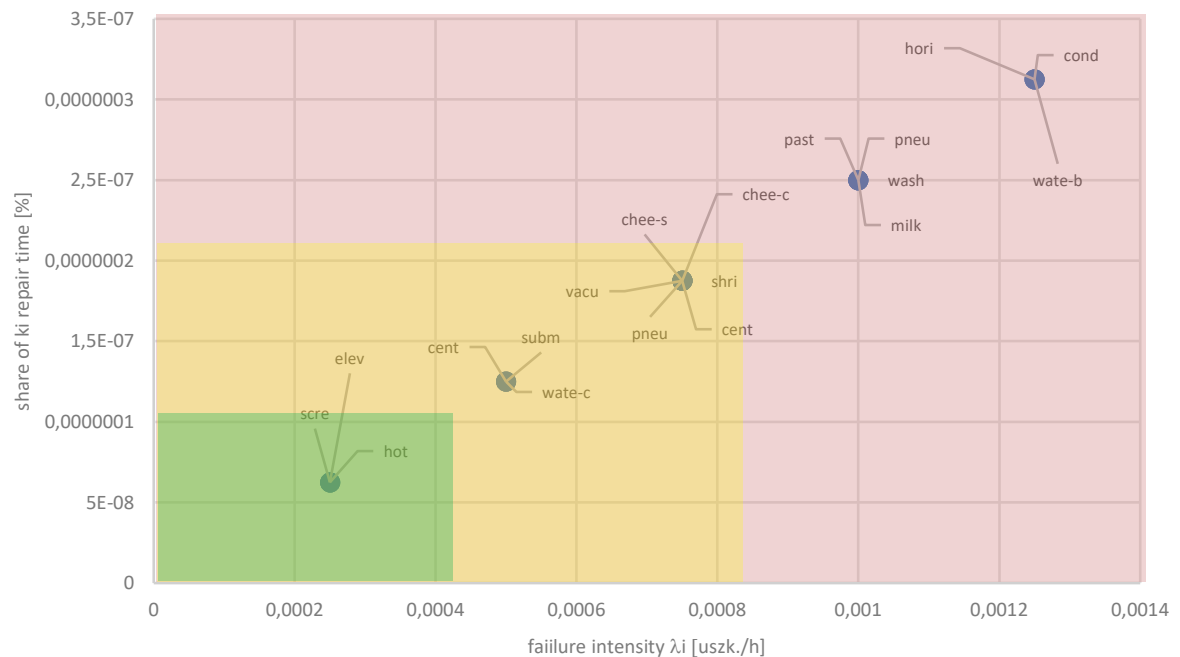

Fig. 8. Risk matrix for the tested devices (V1) 
Based on these assumptions, in the V1 variant, the pieces of equipment with unacceptable risk were the pasteuriser for milk and cream, the pneumatic pump for cheese, the washing station, the milk collection station, the condensing unit, the horizontal tank, the water boiler. In the case of the V2 variant, the pieces of equipment with unacceptable risk were the horizontal tank and the submersible pump. The results of analyses and calculations are summarised in Tables 3 and 4. The description of the adopted category A for the tested devices is presented in Table 5.

\section{RESULTS AND DISCUSSION}

Summarising the results obtained in the conducted analyses, it can be stated that the most rigorous in terms of prioritising the tasks of maintenance services is the method of risk analysis in variant V2, i.e., treating groups of homogeneous pieces of equipment as a single piece. The example of submersible pumps and tanks shows that damage to individual devices is not particularly visible in statistics and analyses, and only the grouping of these devices and

Tab. 3. Summary of the analysis results for variant V1

\begin{tabular}{|c|c|c|c|c|}
\hline \multirow{3}{*}{ CATEGORY } & \multicolumn{4}{|c|}{ EQUIPMENT QUALIFICATION IN ASPECT (V1) } \\
\hline & \multicolumn{2}{|c|}{ SINGLE-CRITERIA PARETO ANALYSIS } & \multirow{2}{*}{$\begin{array}{c}\text { TWO-CRITERIA PARETO } \\
\text { ANALYSIS }\end{array}$} & \multirow{2}{*}{ RISK ANALYSIS } \\
\hline & BY REPAIR TIME & $\begin{array}{l}\text { BY NUMBER OF DAMAGE } \\
\text { INCIDENTS }\end{array}$ & & \\
\hline$A$ & $\begin{array}{l}\text { washing station, } \\
\text { condensing unit, shrink } \\
\text { wrapping machine, } \\
\text { pneumatic press of } \\
\text { cheeses, centrifuge LWG- } \\
47, \text { water cooler, horizontal } \\
\text { tank, water boiler, } \\
\text { pneumatic pump for } \\
\text { cheese, milk collection } \\
\text { station, cheese cauldron, } \\
\text { vacuum packing machine, } \\
\text { cheese cauldron }\end{array}$ & $\begin{array}{l}\text { horizontal tank, condensing } \\
\text { unit, water boiler, washing } \\
\text { station, pneumatic press of } \\
\text { cheeses, shrink wrapping } \\
\text { machine, pneumatic pump } \\
\text { for cheese, centrifuge LWG- } \\
47 \text {, cheese cauldron, vacuum } \\
\text { packing machine }\end{array}$ & $\begin{array}{c}\text { shrink wrapping } \\
\text { machine, centrifuge } \\
\text { LWG-47, pneumatic } \\
\text { press of cheeses, } \\
\text { washing station, } \\
\text { condensing unit, } \\
\text { cheese slurry pump, } \\
\text { cheese cauldron, } \\
\text { vacuum packing } \\
\text { machine, pneumatic } \\
\text { pump for cheese, milk } \\
\text { collection station, } \\
\text { water boiler, horizontal } \\
\text { tank }\end{array}$ & $\begin{array}{l}\text { pasteuriser - milk - } \\
\text { cream, pneumatic } \\
\text { pump for cheese, } \\
\text { washing station, milk } \\
\text { collection station, } \\
\text { condensing unit, } \\
\text { horizontal tank, } \\
\text { water boiler, }\end{array}$ \\
\hline $\begin{array}{c}\text { number of } \\
\text { devices }\end{array}$ & 13 & 10 & 12 & 7 \\
\hline
\end{tabular}

Tab. 4. Summary of the analysis results for variant V2

\begin{tabular}{|c|c|c|c|c|}
\hline \multirow{3}{*}{ CATEGORY } & \multicolumn{4}{|c|}{ EQUIPMENT QUALIFICATION IN ASPECT (V1) } \\
\hline & \multicolumn{2}{|c|}{ SINGLE-CRITERIA PARETO ANALYSIS } & \multirow{2}{*}{$\begin{array}{c}\text { TWO-CRITERIA PARETO } \\
\text { ANALYSIS }\end{array}$} & \multirow{2}{*}{ RISK ANALYSIS } \\
\hline & BY REPAIR TIME & $\begin{array}{l}\text { BY NUMBER OF DAMAGE } \\
\text { INCIDENTS }\end{array}$ & & \\
\hline A & $\begin{array}{l}\text { horizontal tank, } \\
\text { submersible pump, washing } \\
\text { station, condensing unit, } \\
\text { water boiler, shrink } \\
\text { wrapping machine, } \\
\text { pneumatic pump for } \\
\text { cheese, centrifuge LWG-47 }\end{array}$ & $\begin{array}{l}\text { submersible pump, horizontal } \\
\text { tank, washing station, } \\
\text { condensing unit, water boiler, } \\
\text { pneumatic pump for cheese, } \\
\text { milk collection station, } \\
\text { pasteuriser - milk - cream }\end{array}$ & $\begin{array}{l}\text { horizontal tank, } \\
\text { submersible pump, } \\
\text { washing station }\end{array}$ & $\begin{array}{l}\text { horizontal tank, } \\
\text { submersible pump }\end{array}$ \\
\hline $\begin{array}{c}\text { number of } \\
\text { devices }\end{array}$ & 8 & 8 & 3 & 2 \\
\hline
\end{tabular}

Tab. 5. Descriptions and comparison of the adopted damage category

\begin{tabular}{|c|l|l|l|}
\hline CATEgORY & \multicolumn{1}{|c|}{ SINGLE-CRITERIA PARETO ANALYSIS } & TWO-CRITERIA PARETO ANALYSIS & RISK ANALYSIS \\
\hline A & $\begin{array}{l}\text { damage for which the total share in a given } \\
\text { criterion is 80\% }\end{array}$ & $\begin{array}{l}\text { damage with an } \\
\text { unacceptable risk }\end{array}$ \\
\hline
\end{tabular}


their failures shows that they are a serious problem for maintaining the continuity of the company's production. A pure Pareto analysis, especially in the case of small differences in times of correct operation and the number of failures for individual pieces of equipment, is rather of little use as the number of pieces selected in this way is so large that it does not make a significant contribution to the planning of maintenance and repair works.

In maintenance risk analysis tools like RBI or FMEA, fuzzy values such as "very small", "small", etc. are generally used to estimate probability and consequences. Often these values are burdened with a high degree of subjectivity of the authors of these analyzes and result from their personal experiences. In the method proposed in the article, to estimate the probabilities and consequences of damages, "hard" data on times and numbers of failures collected during operation were used. In the method proposed in the article, to estimate the probabilities and effects, "hard" data on the times and numbers of failures collected during operation were used. These data were then processed into commonly known reliability indicators, such as MTBF or failure stream. This means that the adopted values of probabilities and consequences are characteristic of the considered population of machines and devices, and for other populations, they may have completely different values. In this way, it was possible to eliminate the subjectivism of risk assessment and analysis.

\section{CONCLUSIONS}

The perception of maintenance tasks evolved over time from a purely technical role, focused on strict maintenance and repair activities, through preventive and prognostic concepts to proactive, and even intended to be an element of sustainable development. By analogy with the concept INDUSTRY 4.0, MAINTENACE 4.0 comes into use as a technical, technological and even social equivalent. As a result, maintenance as an interdisciplinary field needs appropriate methods and tools that will allow it to achieve its goals effectively and efficiently.

A characteristic feature of traditional, classic tools used in quality management and process improvement (such as the Pareto analysis or the Ishikawa diagram) is their simplicity, efficiency and practically no cost. They allow the identification of qualitative and sometimes also quantitative relationships between various factors in the production pro- cess. Thanks to the use of these methods, it is possible to make decisions that will optimise the use of resources, change the methods of operation and organisation of work, and although they do not create technical or technological progress themselves, they can make a significant contribution. It can be concluded that these tools are mainly applicable to the economic and organisational aspects of maintenance, but they can also identify strictly technical needs, such as creating models for more effective maintenance planning. The article shows how the use of various tools, such as the Pareto analysis, two-criteria Pareto analysis, risk analysis with the use of reliability indicators to estimate the probability of failures and their effects, allows identifying those pieces of equipment whose failures are of key importance for the effectiveness of the production process. It has been shown that the most "restrictive" tool that directs the activities of maintenance services is the risk analysis, which uses operational data that is easy to obtain, i.e., the number of failures and the time required for their removal. It has also been shown that the way of collecting and classifying the collected data is important. Information about the operation of each separate piece should be collected rather than the whole group of pieces operated as one as it may lead to the "blurring" of the problem, which may be important for an enterprise. Naturally, such methods and tools will not make it possible to improve the technical aspect of the maintenance activities related to the prediction and elimination of the effects of various types of wear and fatigue processes taking place in the operated technical facilities. New equipment and methods will be required in such a case, resulting from technological progress and scientific research.

\section{LITERATURE}

Ahlmann, H. (2002). From traditional practice to the new understanding: the significance of the Life Cycle Profit concept in the management of industrial enterprises. Maintenance Management \& Modelling conference. International Foundation for Reseach in Maintenance.

Ahmadi, A., \& Soderholm, P. (2008). Assessment of operational consequences of aircraft failures: Using event tree analysis. 2008 IEEE Aerospace conference, 1-14.

Al-kaabi, H., Potter, A., \& Naim, M. (2007). Insights into the maintenance, repair and overhaul configurations of European airlines. Journal of Air Transportation, 12(2), 27-42.

Arunraj, N. S., \& Maiti, J. (2007). Risk-based maintenanceTechniques and applications. Journal of Hazardous Materials, 142(3), 653-661. 
Bevilacqua, M., \& Braglia, M. (2000). The analytic hierarchy process applied to maintenance strategy selection. Reliability Engineering and System Safety, 70(1), 71-83.

Borris, S. (2006). Total productive maintenance. New York: McGraw-Hill.

Braaksma, A., Johannes, J., Klingenberg, W., \& Veldman, J. (2013). Failure mode and effect analysis in asset maintenance: a multiple case study in the process industry. International Journal of Production Research, 51(4), 1055-1071.

Braglia, M., Castellano, D., \& Gallo, M. (2019). A novel operational approach to equipment maintenance: TPM and RCM jointly at work. Journal of Quality in Maintenance Engineering, 25(4), 612-634.

Braglia, M., Castellano, D., \& Gallo, M. (2019). A novel operational approach to equipment maintenance: TPM and RCM jointly at work. Journal of Quality in Maintenance Engineering, 25(4), 612-634.

Chang, J., \& Lin, C. (2006). A study of storage tank accidents. Journal of Loss Prevention in The Process Industries, 19(1), 51-59.

Coetzee, J. L. (2004). Maintenance. Trafford.

Crawley, F. T. (2015). HAZOP: Guide to best practice. Elsevier.

Drożyner, P., \& Hoffa, P. (2015). Doskonalenie procesów utrzymania ruchu $\mathrm{Z}$ wykorzystaniem narzędzi zarządzania jakością [Improvement of maintenance processes using quality management tools]. Logisty$k a, 6,75-79$.

Drożyner, P., \& Kaczmarek-Jasiulewicz, M., \& Olejnik, K. (2013). The role of maintenance activities to maintain certification of quality, environmental, safety and social responsibility standards. Národné Fórum Družby, 89-95.

Ennouri, W. (2015). Risk management applying FMEASTEG case study. Polish Journal of Management Studies, 11(1), 56-67.

Farrington-Darby, T., Pickup, L., \& Wilson, J. (2005). Safety culture in railway maintenance. Safety Science, 43(1), 39-60.

Fei, L., \& Honghui, Z. H. Y. (1988). Green manufacturing The sustainable development model of modern manufacturing industries. China Mechanical Engineering, 6, 1-24.

Gajdzik, B. (2014). Autonomous and professional maintenance in metallurgical enterprise as activities within total productive maintenance. Metalurgija, 53(2), 269-272.

Gallaba, M., Bouloiz, H., Alaoui, Y. L., \& Tkiouat, M. (2019). Risk Assessment of Maintenance activities using Fuzzy Logic. Procedia Computer Science, 148, 226235.

Galliková, J., Poprocký, R., \& Volna, P. (2016). Implementation of FMEA method in maintenance of semi-trailer combination. Diagnostyka, 17(4), 85-92.

Gharahasanlou, A. N., Mokhtarei, A., Khodayare, A., \& Ataei, M. (2014). Fault tree analysis of failure cause of crushing plant and mixing bed hall at Khoy cement factory in Iran. Case studies in engineering failure analysis, 2(1), 33-38.

Gill, A. (2017). Optimisation of the technical object maintenance system taking account of risk analysis results.
Maintenance and Reliability, 19(3), 420-431. doi: 10.17531/ein.(2017).3.13

Hameed, A., Raza, S. A., Ahmed, Q., Khan, F., \& Ahmed, S. (2019). A decision support tool for bi-objective risk-based maintenance scheduling of an LNG gas sweetening unit. Journal of Quality in Maintenance Engineering, 25(1), 65-89.

Hauge, B. S., \& Johnston, D. C. (2001). Reliability centered maintenance and risk assessment. Annual Reliability and Maintainability Symposium. 2001 Proceedings. International Symposium on Product Quality and Integrity (Cat. No. 01CH37179), 36-40.

Holtz R., \& Campbell P. (2003). Six Sigma: Its implementation in Ford's facility management and maintenance functions. Journal of Facilities Management, 2(4), 320329.

Hu, J., Laibin, Z., \& Wei, L. (2012). Opportunistic predictive maintenance for complex multi-component systems based on DBN-HAZOP model. Process Safety and Environmental Protection, 90(5), 376-388.

Jasiulewicz-Kaczmarek, M., \& Bartkowiak, T. (2016, August). Improving the performance of a filling line based on simulation. In IOP Conference Series: Materials Science and Engineering, 145(4), 042024.

Jasiulewicz-Kaczmarek, M., \& Drożyner, P. (2013). The role of maintenance in reducing the negative impact of a business on the environment. In Sustainability appraisal: Quantitative methods and mathematical techniques for environmental performance evaluation (pp. 141-166). Berlin, Heidelberg: Springer.

Jasiulewicz-Kaczmarek, M., Legutko, S., \& Kluk, P. (2020). Maintenance 4.0 technologies - new opportunities for sustainability driven maintenance. Management and Production Engineering Review, 11(2), 74-87.

Khan, F. I., \& Haddara, M. M. (2003). Risk-based maintenance (RBM): a quantitative approach for maintenance/inspection scheduling and planning. Journal of Loss Prevention in the Process Industries, 16(6), 561573.

Khan, F. I., Sadiq, R., \& Haddara, M. M. (2014). Risk-Based Inspection and Maintenance (RBIM): Multi-Attribute Decision-Making with Aggregative Risk Analysis. Process Safety and Environmental Protection, 82(6), 398-411.

Knights, P. (2001). Rethinking Pareto analysis: maintenance applications of logarithmic scatterplots. Journal of Quality in Maintenance Engineering, 7(4), 252-263.

Kumar, S., Espling, U., \& Kumar, U. (2008). Holistic procedure for rail maintenance in Sweden. Proceedings of the Institution of Mechanical Engineers, Part F. Journal of Rail and Rapid Transit, 222(4), 331-344.

Legutko, S. (2007). Eksploatacja maszyn [Exploitation of machines]. Poznań, Poland: Wydawnictwo Politechniki Poznańskiej.

Legutko, S. (2010). Podstawy eksploatacji maszyn i urządzeń [Basics of exploitation of machines and devices]. Warszawa, Poland: WSiP.

Liberti, S., Ratnaningsih, A., \& Swatama, K. (2019). Assessment of Building Damage using Hazard Identification and Risk Assessment Methods for School Buildings in Jember District. International Journal of Sciences: Basic and Applied Research, 48(6), 55-65. 
Maggard, B., \& Rhyne, D. (1992). Total productive maintenance: a timely integration of production and maintenance. Production and Inventory Management Journal, 33(4), 6-10.

Mańka, I. (2015). Good practices in the field of the risk analysis with the usage of the FMEA method. Forum Scientiae Oeconomia, 3(2), 95-103.

Mareş, R., \& Stelea, M. P. (2017). The application of event tree analysis in a work accident at maintenance operations. MATEC Web of Conferences, 121, 11013. EDP Sciences, 1-6.

Mazur, A., \& Gołaś, H. (2010). Zasady, metody i techniki wykorzystywane $w$ zarzadzanie jakościa [Rules, methodes and techniques utilized in quality management]. Poznań, Poland: Wydawnictwo Politechniki Poznańskiej.

Michalak, A. (2017). Specific risk in hard coal mining industry in Poland. Forum Scientiae Oeconomia, 5(1), 71-77. doi: 10.23762/fso_vol5no1_6

Mikler, J. (2008). Efektywne zarządzanie procesem utrzymania ruchu. Przegląd metod [Effective management of maintenance process. Review of methods]. Retrieved from www.utrzymanieruchu.pl

Mikołajczyk, J. (2013). Wykorzystanie analizy FMEA we współczesnej koncepcji utrzymania ruchu (RCM) [Usage of FMEA analysis in today concept of maintenance]. Zeszyty Naukowe Politechniki Poznańskiej. Organizacja i Zarządzanie, 61, 85-100.

Obora, H. (2008). Zintegrowane podejście G8D-TRIZ w rozwiązywaniu problemów organizacyjnych [G8DTRIZ integrated approach to solving organizational problems]. Prace Naukowe Akademii Ekonomicznej w Katowicach, 127-135.

Onodera, K. (1997). Effective techniques of FMEA at each life-cycle stage. Annual Reliability and Maintainability Symposium, IEEE, 50-56.

Özcan, E., Yumusak, R., \& Eren, T. (2019). Risk Based Maintenance in the Hydroelectric Power Plants. Energies, 12, 1502. doi: 10.3390/en12081502

Pałucha, K. (2015). Wdrażanie innowacji w obszarze organizacji i zarządzania elementem wpływającym na wzrost konkurencyjności przedsiębiorstw [Implementation of innovation in the field of organization and management of competitiveness growth inducing factor]. Zeszyty Naukowe. Organizacja i Zarządzanie, Politechnika Ślaska, 78, 353-366.

Prasanna, N., \& Desai, T. (2011). Quality circle implementation for maintenance management in petrochemical industry. Journal of Engineering Research and Studies, 2(1), 155-162.

Purohit, D. P., Siddiqui, N. A., Nandan, A., \& Yadav, B. P. (2018). Hazard Identification and Risk Assessment in Construction Industry. International Journal of Applied Engineering Research, 13(10), 7639-7667.

Ratnayake, C., \& Antosz, K. (2017). Risk-based maintenance assessment in the manufacturing industry: minimisation of suboptimal prioritisation. Management and Production Engineering Review, 8(1), 38-45.

Saniuk, A., Saniuk, S., Jasiulewicz-Kaczmarek, M., \& Kużdowicz, P. (2015). Efficiency control in industrial enterprises. Applied Mechanics and Materials. Trans Tech Publications, 708, 294-299.
Stanek, K., Czech, P., \& Barcik, J. (2011). Metodologia World Class Manufacturing w fabryce Fiat Auto Poland S.A. [World Class Manufacturing methodology in Fiat Auto Poland S. A. factory]. Zeszyty Naukowe Politechniki Śląskiej, Transport, 71, 65-72.

Starzyńska, B., Hamrol, A., \& Grabowska, M. (2010). Poradnik menedżera jakości. Kompendium wiedzy o narzędziach jakości [Quality manager's guide. A compendium of knowledge about quality tools]. Poznań, Poland: Wydawnictwo Politechniki Poznańskiej.

Stuchly, V., \& Jasiulewicz-Kaczmarek, M. (2014). Maintenance in sustainable manufacturing. LogForum, 10(3), 273-284.

Sutrisno, A., Gunawan, I., \& Tangkuman, S. (2015). Modified failure mode and effect analysis (FMEA) model for accessing the risk of maintenance waste. Procedia Manufacturing, 4, 23-29.

Szczuka, M., \& Drożyner, P. (2015). Metoda charakterystyki dobrych praktyk społecznej odpowiedzialności biznesu [Method of characterizing good practices of corporate social responsibility]. Logistyka, 6 (CD 1), 456-461.

Szpytko, J., Salamonowicz, T., \& Żurek, J. (2003). System wnioskowania decyzyjnego w zakresie obsługiwania urzadzenia [System of decision inference in the field of device operation]. Zagadnienia Eksploatacji Maszyn, 38(2), 139-149.

Todinov, M. T. (2006). Reliability analysis based on the losses from failures. Reliability Analysis, 26(2), 311-335.

Vassilakis, E., \& Besseris, G. (2009). An application of TQM tools at a maintenance division of a large aerospace company. Journal of Quality in Maintenance Engineering, 15(1), 31-46.

Vaurio, J. K. (2010). Ideas and developments in importance measures and fault-tree techniques for reliability and risk analysis. Reliability Engineering \& System Safety, 95(2), 99-107.

Wireman, T. (1990). World class maintenance management. New York: Industrial Press.

Yi, X. J., Chen, L., Shi, J., Hou, P., \& Lai, Y. H. (2017). A maintenance evaluation method for complex systems with standby structure based on goal oriented method. IEEE International Conference on Industrial Engineering and Engineering Management (IEEM), IEEE, 2130-2134.

Yi, X. J., Dhillon, B. S., Shi, J., Mu, H. N., \& Dong, H. P. (2016). Reliability analysis method on repairable system with standby structure based on goal oriented methodology. Quality and Reliability Engineering International, 32(7), 2505-2517.

Żółtowski, B., \& Niziński, S. (2010). Modelowanie procesów eksploatacji [Modelling of exploitation processes]. Radom, Poland: Wydawnictwo Naukowe Instytutu Technologii Eksploatacji PIB.

Żółtowski, B., \& Tylicki, H. (2004). Wybrane problemy eksploatacji maszyn [Chosen issues of machine exploitation]. Piła, Poland: Państwowa Wyższa Szkoła Zawodowa im. Stanisława Staszica.

Żurek, J. (2004). Analiza systemu eksploatacji z punktu widzenia kosztów i niezawodności [Analysis of exploitation system in terms of cost and reliability]. Zagadnienia Eksploatacji Maszyn, 39(4), 117-126. 